\title{
Evaluation of the Teacher Education Programs in EFL Context: A Testimony of Student Teachers' Perspective
}

\author{
Abdul Karim \\ Lecturer, BRAC Institute of Languages (BIL), BRAC University, Bangladesh, \\ khasan13aiub@gmail.com \\ Faheem Hasan Shahed \\ Assoc. Prof., BRAC Institute of Languages (BIL), BRAC University, Bangladesh, \\ faheembangladeshi@gmail.com
}

\author{
Abdul Rashid Mohamed \\ Prof., School of Educational Studies, Universiti Sains Malaysia, Malaysia, \\ richsesusm@gmail.com
}

\section{Mohammad Mosiur Rahman}

$\mathrm{PhD}$ Student, School of Languages, Literacies and Translation, Universiti Sains Malaysia, Malaysia, mosiurbhai@gmail.com

\section{Shaik Abdul Malik Mohamed Ismail}

Assoc. Prof., School of Educational Studies, Universiti Sains Malaysia, Malaysia, samohame@gmail.com

Pre-service teacher education programs such as, TEFL, TESOL, and ELT are offered in some universities in Bangladesh. Meeting the criteria and based on their level, students tend to enroll in BA in TEFL or TESOL and MA in TESOL or ELT programs. These programs entail different courses that are claimed to enable enrollees with the repertoires required to be an expert language teachers. However, for unknown reason, the effectiveness of such teacher education programs has not been explored. The current study intended to reveal what student teachers think about their teacher education programs. Adopting the pre-service teacher education program evaluation model suggested by Peacock, the current study was conducted. Semi-structured interview with the selected participants was also undertaken. Conducting the descriptive statistics elicited the respondents' perceptions regarding the teacher education programs. Majority of the participants viewed the programs instrumental to develop their pedagogic and linguistics competence.

Keywords: EFL teacher education, evaluations, teacher learning, perceptions, student

Citation: Karim, A., Shahed, F. H., Mohamed, A. R., Rahman, M. M., \& Ismail, S. A. M. M. (2019). Evaluation of the Teacher Education Programs in EFL Context: A Testimony of Student Teachers' Perspective. International Journal of Instruction, 12(1), 127-146. https://doi.org/10.29333/iji.2019.1219a 


\section{INTRODUCTION}

The compelling issue regarding English concerns its inevitability as lingua franca in the global village. Certainly, the education program for EFL teacher is globally underscored, given their instrumentality to equip teachers to secure English language learning environment for the students. Cynically, only a handful number of research has been carried out globally with regard to the overall evaluation of EFL teacher education programs. Literature related to this field witnessed few studies, e.g., Seferoglu (2006), Peacock (2009), Coskun and Daloglu (2010), Kerakas (2012), Akcan (2016) and Agudo (2017). However, these studies are reported as contextually biased and concerned with the operation of such programs in their own settings. Considering such phenomenon, Agudo (2017) recommends more studies to be conducted in relation to EFL teacher education programs. Typically, program evaluation is subject to "the collection, analysis, and interpretation of information (...) for forming judgments about the value of a particular program" (Robinson, 2004, p. 199). Teacher education programs should be critically scrutinized, adopting a procedure for overall internal evaluation by regularly assessing its strengths and weakness and eliciting suggestions and recommendations for program improvement (Peacock, 2009). To secure the effectiveness of TEFL, TESOL or ELT programs and teacher quality, consistent evaluation is rigorously emphasized (Musset, 2010).

Generally, a teacher is perceived as an instrumental figure in the learner's learning process. According to Darling-Hammond (2017), for most of the nations, teaching has been identified to occupy an impressionable position in the education policy. Students' achievement is determined by the quality of teaching. Teacher preparation and development are thus reported as key elements, yielding effective teachers. However, the past few decades have been the years of constant debate concerning the knowledge and skills required to be an effective teacher. Zeichner, Payne and Brayko (2015), therefore, elaborate on this stating that the issue underpinning the debate regarding teacher education and teacher quality is highly oriented to the scale of knowledge and skills necessitated to promote students' high academic standards. Given its centeredness in the national education policies (Shohel \& Banks, 2012), teacher education becomes didactic for the development of teaching quality and students' learning (Karim, Mohamed \& Rahman, 2017). As such, it is needless to say that teacher education is quintessential to the teaching profession. Perhaps, that is why the writings over the years pertain extensively about what beginning teachers need to know and be able to do (e.g., Darling-Hammond \& Bransford, 2005). In addition, teacher education has been sectionalized over the years. The ones identified according to Zeichner et al.'s (2015) elaboration are college-recommending teacher education and early entry programs. College-recommending teacher education concerns the translations of academic knowledge into practice. In such programs, enrolees learn what and how to teach, and then apply what they have learned in schools. It is blatantly evident that rarely do the candidates in teacher education program experience the synchronization of what is done in the course and field components of the teacher education program (Anderson \& Stillman, 2011; Zeichner, 2010). Considering the EFL context, more often than not, teachers experience potential difficulty to incorporate what is learned in their 
pedagogical practice. However, the rapid expanded "early-entry" programs situate newbie teachers in schools with handful amount of pre-service preparation and emphasize on practice and practitioner. Such programs tend to create irrational glorification concerning their deeds and minimize the importance of professional education coursework, given they view coursework as indirectly connected to daily teaching affairs. Zeichner et al. (2015) identify such act as falsely framed by them since they believe that teacher education program should be designed either incorporating the theory or practice. They, sometimes, curtail theory from teacher preparation. From Zeichner et al.'s (2015) elaboration we are certain regarding to schools of thought related to teacher education program. Some contexts witness the imbibitions of theory and practice. For instance, in Bangladesh teacher education programs orient both theory and practice. Courses are designed considering both the elements. This study intended to evaluate the pre-service teacher education programs, undertaking a framework developed by Peacock (2009). The study concerned Bangladeshi context, in particular, the programs such as, Teaching English to Speakers of other Languages (TESOL), Teaching English as a Foreign Language (TEFL) and English Language Teaching (ELT) offered by the universities.

\section{LITERATURE REVIEW}

In conjunction with the national level, the teacher education paradigm has been recognized internationally with simultaneous penetration carried out in the general education system (Coskun \& Daloglu, 2010). Studies pertinent to English Language Teaching (ELT) have integrated diversified aspects. Of particular area covered by such investigations was English teacher education which elaborated on the quality of the program and their impacts on classroom practice. Such investigations, for the most, incorporated the impact of in-service teacher education program on the classroom practice. Coskun and Daloglu (2010), however, point out the importance of structured evaluation system of pre-service teacher education programs, suggesting the modifications or revisions to be accomplished in relation to the programs. This section subsumes the studies carried out so far regarding the investigation of the programs. The final part includes the studies and results of the evaluation done globally.

Peacock (2009) explicates that evaluation of these programs provide educators with the scaffold towards professionalization in the field of ELT. Rea-Dickens and Germaine (1993) call for the systematic evaluation to be placed at the core of a program, given its contribution to the program improvement. In addition, the number of studies concerning the evaluation of pre-service English teacher education program is relatively less (Coskun \& Daloglu, 2010). For instance, foreign language teacher education is relatively new in comparison to the education in other areas, and consequently, studies pertaining to this are also few in number (Day, 1991; Weir \& Roberts, 1994). Apart from this, little attempt has been accelerated to develop a model or design that precedes the evaluation of such programs (Coskun \& Daloglu, 2010). In terms of the evaluation of the English teacher education program, the one conducted by Coskun and Daloglu (2010) reports the accord of student teachers regarding the pedagogical weakness of the program, provided this study harness the questionnaire suggested by Peacock (2009). 
They also claim that the program is not offering adequate practice opportunities. Such responses from the students are commensurate with the findings uncovered by Seferoglu (2006), Erozan (2005) and Salli-Copur (2008). The lack of realism and practice opportunities in the program underpins students' argument for more pedagogic courses and chance for teaching practice. The study reveals the demand of the student teachers for a practice-oriented course in the first and in the last year of the program. Along with this is the demand for a course providing them with the opportunities to reflect "on their school experiences and get feedback from each other as well as from the teacher" ( $p$. 35). Furthermore, investigating into the perspective of the students and graduates, study - for uncovering the strengths and weaknesses of an English teacher education program in Saudi Arabia - conducted by Al-Gaeed (1983) showed that the then students and graduated found the program effective regarding the classroom practice of the teacher, teaching methodology, the quality of the teacher educators and offered linguistic courses, although the participants reported the downsides resulted from insufficient oral communication. Provided the anxiety factors experienced by the South African teachers at the beginning, a study carried out by Barkhuizen (1997) interviewed 120 senior student teachers to mitigate this problem. The responses suggested that students concerned low proficiency of the learners, their attitudes, L1 interference, and the effectiveness of the teachers. Exploiting values, skill, and knowledge (VSK) framework, Chong and Cheah (2009) conducted a study in Singapore. Through a program evaluation, the study looks at the validity and reliability of the items generated by VSK framework, in an attempt to assess the value, skills and knowledge perceived by the student teachers participating in their education program undertaken prior to teaching. Chong and Cheah (2009) reported that the graduating students are provided with maxims of teaching and learning under VSK framework, although it lacks the potentiality to implement these in practice. Considering teacher education program in Spanish context, study carried out by Agudo (2017) reveals that the TEFL program adequately cover pedagogic competence, although the linguistic component are identified weak. This study exploits the education program evaluation questionnaire developed by Peacock (2009).

The studies conducted so far concern different EFL contexts, delving the perception of the student teachers regarding the components of the teacher education programs. As such, the importance of conducting such evaluation subjected to Bangladeshi teacher education programs can never be disputed. The study is meticulously significant in the context of Bangladesh based on two grounds. Firstly, these pre-service student teacher education programs are introduced in Bangladesh by different universities have never been explored before. Thus, it will contribute to the overall scholarship in the field through reporting a new context. Secondly, we explored Bangladesh considering its unique features as a context that has scoped niche for the study. Bangladesh, unlike other EFL contexts, is positioned uniquely in the middle of ESL and EFL McArthur (1996). It has all the features required to be identified as ESL; however, based on the use of English it can be defined as EFL context (Ali \& Walker 2014). In such context, significance of TEFL or TESOL or ELT programs can have vivid impressions than other EFL or ESL settings that underwent investigations. Therefore, the students of 
TEFL or TESOL or ELT also need to be armed with different techniques to confront the ELT issues in Bangladesh. Thus, the importance of conducting such evaluation subject to Bangladeshi teacher education programs can never be belittled. Drawing the following research questions, the current study intended to evaluate the teacher education programs in Bangladesh.

1. Do student teachers believe that the current teacher education programs meet their needs and expectations, and thereby, adequately prepare them for EFL teaching?

2. How do the student teachers deem the teacher education programs?

An extensive knowledge base necessitated for individual language teacher to teach students from diverse linguistics and socio-cultural backgrounds is to be identified as a cornerstone for a good teacher (Richards, 2010). The inculcation of such knowledge base in to the about-to-be teachers (see Wallace, 1992; Day, 1993; Lucas \& Villegas, 2013) is the ultimate goal of pre-service teacher education programs (Mann, 2005). In order to teach, the most important mechanism needed by a teacher is the preparation for teaching. In the initial stage-first year of teaching - preparation is critical since they are newbie in this profession (Lucas \& Grinberg, 2008). However, when novices enter the field of language teaching they become involved in many different dimensions of learning and discovering themselves as a teacher that demands to adapt customized changes (Pennington\& Richards, 2016). This preparation incorporates pre- service teacher preparation programs, development of teacher knowledge bases like pedagogical and linguistics competence. One of the most significant preparations associated with the quality of novice teachers and professional development is to attend formal teacher education program (Coady, Harper and Jong, 2011). According to the findings of Menken \& Antuñez (2001), teachers who had attended formal education programs, like TESOL, TEFL and ELT, are likely to be well-prepared and well-informed in terms of TESOL or ESOL issues. This is aligned with our focus of the study e.g., how these programs develop teachers' knowledge base. Athanases \& de Oliveira, (2008) advocates the importance of attending education program before entering in English language classroom by pointing the advantages these teachers get in the pedagogical decision making.

\section{METHOD}

This section was developed to highlight the context of the study, research design, participants of the study, data collection procedure and data analysis.

\section{The Context}

There are different kinds of pre service student teacher education programs which are available in Bangladesh that are offering both in undergraduate and post graduate level. Such programs range from but not confined to 'BA in English' (majoring in ELT, TESL, TEFL, TESOL etc), 'MA in ELT' and 'MA in TESOL'. In undergraduate level, based on the quality of the university, the requirements are varied. However, in MA the requirements are based on several issues, considering the professional nature of the study such as previous educational background, academic results, motivation of study etc. It is assumed that the MA in TESOL or MA in ELT is a professional degree for 
prospective or novice teachers who want to be trained as an English teachers. We selected our relatively small sample of the study from the major private universities in Bangladesh. It may be argued that they are not representative of the whole population if we consider that the numbers of the private universities is 86 (University Grant Commission, 2018).

The public universities in Bangladesh do not typically offer any concentration area pertaining to English teaching in undergraduate level. The curricula have been developed focusing mostly on Literature and Linguistics. However, some universities seem to offer one or two courses to introduce Applied Linguistics and ELT. Nevertheless, concerning the 'BA in English' being majored in TEFL or TESOL, the private universities in Bangladesh designed the curricula incorporating the courses that are believed to be sufficient for preparing efficient and skilled teachers of English. It is worth mentioning that very few universities offer BA in English degree with concentration on courses in the field of TEFL or TESOL. "A", a leading private university in Bangladesh with esteemed reputation, offers BA in English program designed with major in TESOL courses such as, Introduction to Applied Linguistics, Theories of Language Acquisition, Principles of Syllabus Design \& Material Development, Testing and Evaluation and Teaching Techniques \& Practicum. For admitting at the "A" University, students have to have combined GPA (Grade Point Average) of 8.00 (out of 5) in both Secondary School Certificate (SSC) and Higher Secondary Certificate (HSC) examinations. For O-Levels in 5 subjects with average grade point 2.5 or above and A-Levels in two subjects with average grade point of 2.00 (Scale $\mathrm{A}=5, \mathrm{~B}=4, \mathrm{C}=3$ and $\mathrm{D}=2$ ) are required. "B" University designed its BA in English program facilitating opportunity for the students to choose their major from three areas, Literature, Applied Linguistics and ELT, and Media and Cultural Studies. As such, students majoring in Applied Linguistics and ELT are offered with compulsory courses such as, Sociolinguistics, Psycholinguistics, Discourse Analysis, Teaching Techniques, Second Language Acquisition, Material Design, Testing and Evaluation and Teaching practicum. GPA 3.50 in both SSC and HSC are required to get the students apply for admission. In terms of A-Levels and O-Levels, the requirement is the same as $\mathrm{A}$ University. "C", one of the prominent universities in Bangladesh, also facilitates students in BA in English program to major in TEFL. Consequently, the courses offered here regarding TEFL are Syntax and Semantics, Psycholinguistics, Syllabus Design, Material Development, Second Language Acquisition and Development, Teaching Reading, Teaching Writing, Teaching Listening and Speaking, and Teaching Grammar. Teaching Practicum is also offered here as one of the electives. Applicants have to have combined GPA of 5.50 in both SSC and HSC examinations to get take part in the admission test. Apart from such requirements, all the universities allow international Baccalaureate holders to get admission.

Candidates considered eligible to enrol in MA in TESOL or ELT program must complete their Bachelor's degree in English Language/Literature/Linguistics/Applied Linguistics/ ELT from recognized universities. However, candidates having major in other subjects in Bachelor of Arts (BA) program are also considered eligible to get admitted into this program with some additional requirement. In the case of "D" 
University, for instance, such candidates have to have 4-year education in the university level in conjunction with current teaching profession in either primary or secondary or higher secondary or any other level. They must submit a record of two-year experience in teaching English, which has to be endorsed by the head of the institution. "E" University requires the similar qualification to admit, but unique in that candidates here need not hold teaching profession or experience. The private universities also require the same qualification to get the candidates admitted into the program. However, "A" University, for candidates with Bachelor's and/or Masters degree except English, requires an MA or MS in subjects of liberal arts and social sciences. Students enrolled in such programs are provided with adequate learning materials in the form of book, handout, brief notes, demo contents, photocopies and so on. Below is the overview (Diagram 1) of the requirements for admission set by the universities in different degree programs.

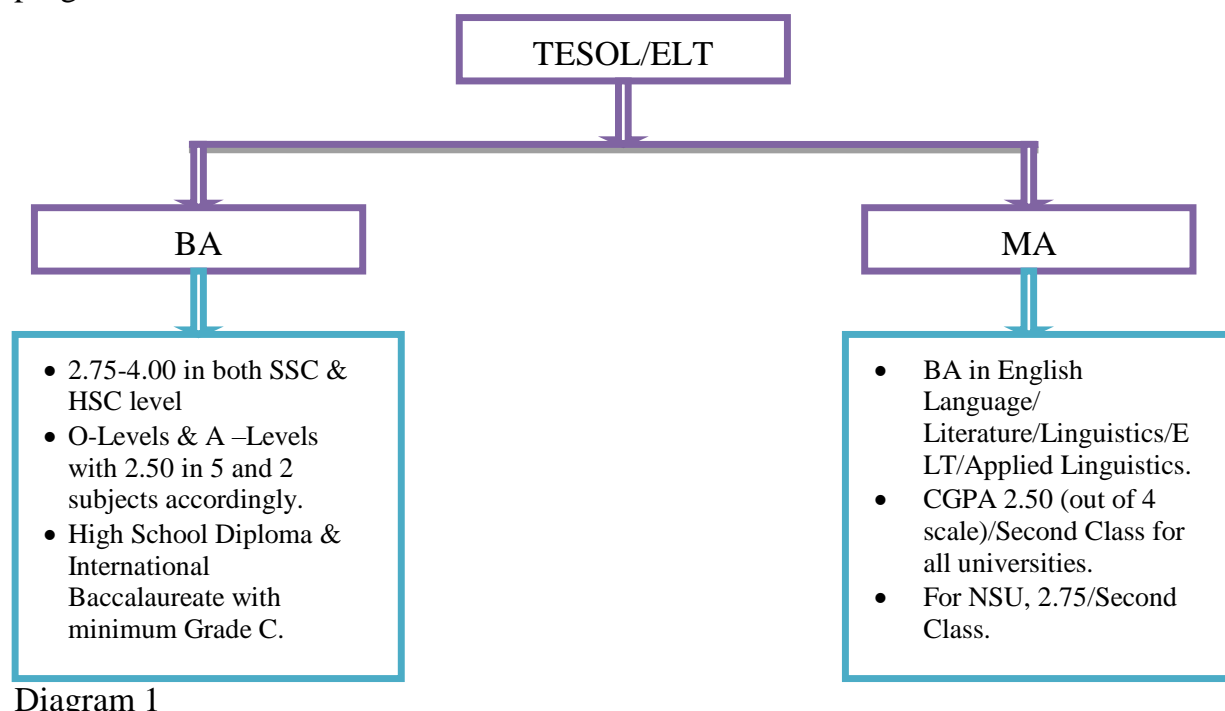

Criteria for enrollment in BA in TEFL/TESOL or MA in TESOL/ELT programs Course Outline of the Programs

In Bangladesh, graduate programs are also offered with major in ELT in both public and private universities that are heading toward shared aim and objectives. Generally, English teachers in both schools and colleges (Bengali and English medium) tend to enroll in such graduate programs. Surprisingly, English teachers in university level also tend to take admission in order to reshape their thoughts related to English teaching, given they had graduated majoring in either literature and linguistics in quite earlier days. MA in TESOL or ELT program has been designed to equip the student teachers to teach learners learning English as a second or foreign language. They radicalize their TESOL or ELT programs by incorporating a good dose of theory and criticism. However, there is a slight variation observed in terms of offered courses. For instance, 
"A" University offers MA in TESOL program incorporating courses such as, History of English Language, Theories of Language Learning and TESOL, Methods and Techniques for TESOL, Research Methods in TESOL, Approach to Teaching Grammar, Topics, Issues and Trends in TESOL I, Second Language Development, TESOL Material Development, Measurement and Evaluation for TESOL, TESOL in Bangladesh, ELT Syllabus design, Dynamics of Language Policy and Planning in Bangladesh, Media and Teaching of English, Topics, Issues and Trends in TESOL II, Practicum for Teaching English to Speakers of Other Languages, Critical Reading and Teaching English to Speakers of Other Languages at the Secondary and Tertiary Levels. Another private university named "F" offers courses pertaining to Syllabus design, Material development, Teaching Methodology, Testing and Teaching the four language skills. Independent University, one of the reputed private universities, offers courses such as, The history of English Language Teaching, Linguistics and Language Teaching, English Phonetics and Phonology, Current Issues in English Language Teaching, Syllabus design, Material Development, Testing and Evaluation, Second Language Learning and Acquisition Theories, Psycholinguistics and Language Teaching, ELT research Methodology and Teaching Practicum. In the same vein, "B" University, one of the prominent private universities, designs their MA in TESOL program including major courses like Methods and Practice of Teaching ESL, Syllabus, Curriculum and Materials Design and Evaluation, Second Language Acquisition and Psycholinguistics, Language Testing and Evaluation, Use of Technology in ELT, Classroom Research and Research Methods in ELT and Teaching Practicum I and II. Furthermore, there are some public universities offering MA in ELT, but different in that some of them offer weekend program majoring in ELT. E University, for example, offers weekend MA in ELT aiming at equipping students in various facets of applied linguistics and EFL teaching. The particular intention of this program is to produce diverse professionals and well-equipped English language teachers. Courses offered in this program are English Phonetics and Phonology, English Morphology and Syntax, Approaches and Methods in ESL/EFL Teaching, Language Teacher Education, ESL/EFL Syllabus Design, ESL/EFL Materials Development, Teaching ESL/EFL Skills, ESL/EFL Testing, Psycholinguistics, Sociolinguistics, Technology in ESL/EFL Teaching and Practice Teaching and Presentation. Institute of Modern Languages at " $D$ " University also offers MA in ELT program for aspiring and practicing teachers of English. Similar courses are offered here like the previous ones with an additional course namely Education Psychology. Diagram 2 illustrates an overview of the courses typically taught in BA in TEFL/TESOL and MA in TESOL or ELT programs in Bangladeshi universities. Since there is commonality prevailing among courses offered by different universities, single diagram is undertaken to exhibit these. 


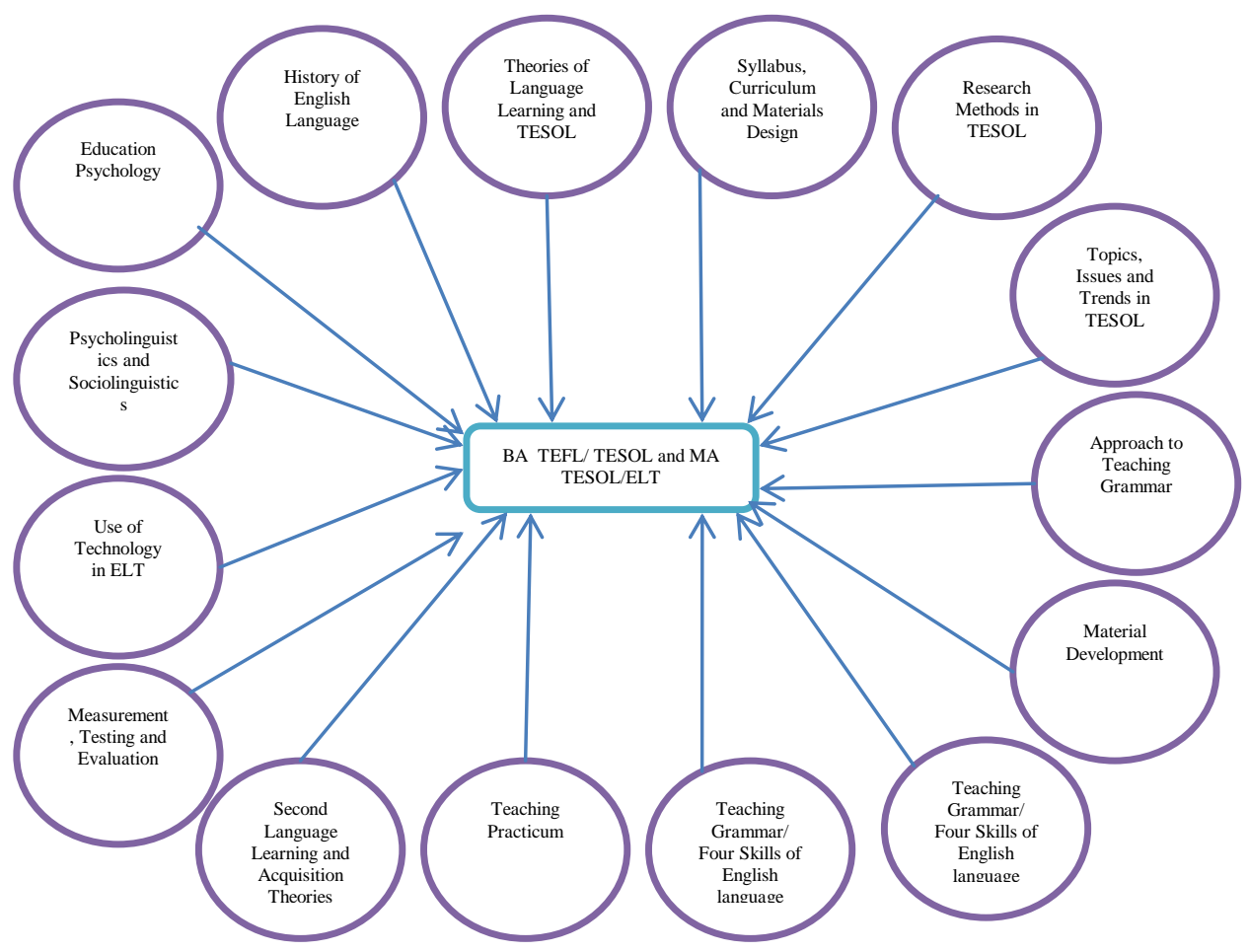

Diagram 2

Courses offered in BA in TESOL/TEFL and MA in TESOL/TEFL/ELT programs

As regards materials, students enrolled in such programs are provided with adequate learning materials in the form of book, handout, brief notes, demo contents, photocopies and so on.

\section{Research Design}

Considering the nature of the questions that were posed earlier, we undertook both quantitative and qualitative research methods to uncover the views of student teachers regarding the value and effectiveness of the current EFL teacher education program. Mixed-methods approach was incorporated since it calls for the collection, analysis, and mixture of both quantitative and qualitative data at different stages of the research process (Hamid, Sussex \& Khan, 2009). This research design was based on the "premise that the use of quantitative and qualitative approaches in combination provides a better understanding of research problem than either approach alone" (Plano Clark, 2007, p. 5). Quantitative aspect of the study revealed the research question-1, in order to generate maximum amount of data from the participants to reveal whether or not student teachers believe that the current teacher education programs address their requirements, and consequently, equipping the student teachers to become teachers in an EFL context that is embarking on achieving English proficiency for its citizens in oral and written form 
(see Bryman, 2012). Research question-2 was approached qualitatively, specially a phenomenology approach has been adopted (Creswell \& Puth, 2017), in order to reveal in depth understanding of the phenomenon in relation to the experience of the participants that how pre-service teacher educator deem their teacher training degree successful.

\section{Participants of the Study}

The nature of the study acted as a decisive factor to select the sample of the study. Hycner (1993) elucidates, "the phenomenon dictates the method including the type of participants" (p. 156). In order to select the participants, a purposive sampling technique was adopted. According to Cohen, Manion and Morrisson (2013), deliberate intervention on the sampling process is known as purposive sampling. We set the criterion such as, BA in TEFL graduate, and students who had already completed their MA in TESOL or ELT, and were working as English teachers in either Bengali or English medium schools. After the completion of their BA in TEFL or TESOL, they started MA in ELT and TESOL. Simultaneously, they were serving as English language teachers in the secondary (Grade 6 to 10) schools. The rationale behind the first criterion was that these participants could elicit the best feedback since they had been applying their knowledge in classrooms as practising teachers. It is worth mentioning that respondents in this study were from different universities which offer BA/ or MA in TEFL or TESOL or ELT. As aforesaid, the courses in the programs were similar-there was no distinction associated with the participants concerning the courses they had enrolled. Therefore, the participants were homogeneous in nature based on the criterion that all of them had completed their studies, and were teaching English in different schools in Bangladesh. Only ELT professionals were selected because they were believed to be more pragmatic in relation to eliciting the feedback since they have practical exposure to teaching.

Initially, the questionnaire was sent to 154 student teachers. After receiving their responses, 44 questionnaires were found incomplete, and consequently, their responses were excluded. Finally, the number of participants considered to carry out the study was 110. It is worth mentioning that the participants were dubbed sometimes as student teachers and participants/respondents interchangeably, given their previous identity as students of teacher education programs and the current identity as English teachers. However, studies (e.g., Peacock, 2009; Coskun \& Daloglu, 2010; Agudo, 2017) also dub the enrolees of such programs as student teachers with the belief that they would be English teachers somewhere down the line.

In the qualitative part of the study, a face-to-face semi-structured interview was conducted. Eight student teachers were selected for the interview. In phenomenology study, the ideal size of the sample is not fixed in literature; however, as per the recommendation of Cohen et al. (2013) and also Creswell (2013), the ideal sample size should be kept under ten (10) cases. Since, interpersonal relationship should be developed during the qualitative data collection, this size allowed to build it during the study and helped to get information in a more detailed manner. 


\section{Instrumentation and procedure for Data collection}

To collect detailed information about how Bangladeshi EFL student teachers actually perceive the effectiveness of the teacher education programs, the questionnaire was administered among the participants through online using Google survey form. The questionnaire exploited in this study was adopted from Peacock's (2009) study. The questionnaire contained 22 closed-ended items referring to, as Agudo (2017) elaborates, the elements of adequate 'training of EFL teachers'. Respondents were asked to express their degree of agreement or disagreement on a 5-point Likert scale ranged from 'strongly disagree' to 'strongly agree'. Coskun and Daloglu (2010) remark Peacock's (2009) model for evaluation as "effective in providing multidimensional feedback about the program being evaluated" (p. 38).

To elicit student teachers' view about the teacher education programs, a semi-structured face to face interview protocol was conducted. The interview was taken from 8 participants. Selective questions were administered among the participants, provided that the questions were adapted from Peacok (2009). Some questions were excluded in order to reduce redundancy since they have already been asked in the quantitative questionnaire. We kept our focus to extract teachers' perception and knowledge regarding the course they had attended, how well they had understood the philosophy of the course, how flexible to attend the classes for trainee teachers, the content of focus for the course, and lastly, how the course had contributed to the development of their knowledge-building. Our intention was to be able to elicit some new insights from the responses generated from the teachers.

\section{Data Analysis}

Prior to administering the questionnaire, a consultation was carried out with an expert in order to check the suitability of the questionnaire and semi-structured interview in Bangladeshi evaluation context, with a view to achieving construct validity. The feedback suggested no modification. Data collected through questionnaire were subject to SPSS 23 analysis that yielded descriptive data. The Kaiser-Mayer-Olkin (KMO) measure of sampling adequacy was estimated .520 , technically acceptable to conduct the study. A frequency table was developed to illustrate the responses of the participants.

The first step of qualitative data analysis was reading and writing the memos containing all the data. According to Gay and Airasian (2003), it is important to keep notes in the margined area, as these will allow researchers to record initial interpretations of the data. The interview data will be organized thematically (Creswell \& Puth, 2017). The analysis was divided into two phases: vertical analysis and horizontal analysis (Flores, 2005). In vertical analysis, data from each respondent was analysed separately and relevant information based on the keywords was arranged into themes. In horizontal analysis of data, all the interview responses were analysed together forming a comparative analysis or cross-case analysis (Flores, 2005).

The study strived to reveal how the student teachers have found their pre-service education course. The findings of the qualitative data were generated through the interview questionnaire. Our questionnaire was developed in a manner that had 
contributed to the development of the theme very easily. After the careful reading, memoing and analysis of the excerpts from the interviewees, four major themes were emerged. The semi-structured interview was analysed in following themes: clarity of program philosophy; flexibility of the program; focus of the program; capability building for instructional materials; teacher knowledge building. These themes were formed on the basis of teachers' evaluation of their desire and experience with regard to the respective teacher education programs.

\section{FINDINGS}

The findings of the study were divided into quantitative part and qualitative part.

\section{Quantitative finding}

Table 1

Percentages of respondents selecting each alternative

\begin{tabular}{|c|c|c|c|c|}
\hline Strongly disagree & Disagree & $\begin{array}{c}\text { Neither agree nor } \\
\text { disagree }\end{array}$ & Agree & Strongly Agree \\
\hline \multicolumn{5}{|c|}{$\begin{array}{c}\text { The TEFL/TESOL/ELT program... } \\
\text { Statement } 1 . \ldots \text { has good linkage between different courses. }\end{array}$} \\
\hline $4 \%$ & $6 \%$ & $4 \%$ & $14 \%$ & $72 \%$ \\
\hline \multicolumn{5}{|c|}{ Statement $2 . \ldots$ Avoids overlapping information between different courses. } \\
\hline $3 \%$ & $6 \%$ & $15 \%$ & $24 \%$ & $52 \%$ \\
\hline \multicolumn{5}{|c|}{ Statement $3 . .$. gave me adequate training in English. } \\
\hline $2 \%$ & $8 \%$ & $3 \%$ & $13 \%$ & $74 \%$ \\
\hline \multicolumn{5}{|c|}{ Statement $4 . .$. gave me adequate training in teaching skills. } \\
\hline $1 \%$ & $1 \%$ & $3 \%$ & $15 \%$ & $80 \%$ \\
\hline \multicolumn{5}{|c|}{ Statement $5 \ldots$... gave me adequate training for the needs of the local context (teaching in Bangladeshi schools) } \\
\hline $3 \%$ & $17 \%$ & $18 \%$ & $28 \%$ & $34 \%$ \\
\hline \multicolumn{5}{|c|}{ Statement $6 . .$. is up-to-date. } \\
\hline $8 \%$ & $4 \%$ & $8 \%$ & $4 \%$ & $76 \%$ \\
\hline \multicolumn{5}{|c|}{ Statement $7 \ldots$...encouraged me to reflect on my past experiences as a language learner. } \\
\hline $11 \%$ & $4 \%$ & $7 \%$ & $8 \%$ & $70 \%$ \\
\hline \multicolumn{5}{|c|}{ Statement $8 . \ldots$ encouraged me to be a reflective teacher (when I start teaching). } \\
\hline $10 \%$ & $4 \%$ & $17 \%$ & $6 \%$ & $73 \%$ \\
\hline \multicolumn{5}{|c|}{ Statement $9 . \ldots$ promotes flexibility in using different teaching practices for different situations. } \\
\hline $11 \%$ & $9 \%$ & $16 \%$ & $8 \%$ & $56 \%$ \\
\hline \multicolumn{5}{|c|}{ Statement $10 \ldots$ balances teacher-centered and student-centered learning on its courses. } \\
\hline $17 \%$ & $8 \%$ & $18 \%$ & $9 \%$ & $48 \%$ \\
\hline \multicolumn{5}{|c|}{ Statement $11 . .$. taught me how to teach English. } \\
\hline $2 \%$ & $1 \%$ & $3 \%$ & $8 \%$ & $86 \%$ \\
\hline \multicolumn{5}{|c|}{ Statement $12 . .$. taught me how to evaluate myself as a teacher. } \\
\hline $2 \%$ & $2 \%$ & $9 \%$ & $0 \%$ & $87 \%$ \\
\hline \multicolumn{5}{|c|}{ Statement 13 ....taught me classroom management skills. } \\
\hline $12 \%$ & $3 \%$ & $23 \%$ & $4 \%$ & $58 \%$ \\
\hline \multicolumn{5}{|c|}{ Statement $14 . \ldots$ taught me how to use foreign language teaching materials. } \\
\hline $1 \%$ & $1 \%$ & $4 \%$ & $16 \%$ & $78 \%$ \\
\hline \multicolumn{5}{|c|}{ Statement $15 \ldots$ taught me how to adapt foreign language teaching materials. } \\
\hline $12 \%$ & $3 \%$ & $24 \%$ & $5 \%$ & $56 \%$ \\
\hline \multicolumn{5}{|c|}{ Statement $16 . .$. increased my powers of self-evaluation. } \\
\hline $2 \%$ & $1 \%$ & $1 \%$ & $1 \%$ & $95 \%$ \\
\hline \multicolumn{5}{|c|}{ Statement $17 \ldots$ foreign language testing and evaluation skills. } \\
\hline \multirow{2}{*}{\multicolumn{5}{|c|}{$\begin{array}{c}3 \% \\
\text { Statement } 18 \ldots \text { is relevant to my needs. }\end{array}$}} \\
\hline & & & & \\
\hline $3 \%$ & $3 \%$ & $3 \%$ & $3 \%$ & $88 \%$ \\
\hline \multicolumn{5}{|c|}{ Statement $19 . \ldots$ has a good balance between the teaching of: English, teaching skills, and classroom management skills } \\
\hline $7 \%$ & $5 \%$ & $11 \%$ & $9 \%$ & $68 \%$ \\
\hline \multicolumn{5}{|c|}{ Statement $20 . \ldots$ prepared me to teach English in the classroom. } \\
\hline $6 \%$ & $7 \%$ & $4 \%$ & $8 \%$ & $75 \%$ \\
\hline \multicolumn{5}{|c|}{ Statement $21 \ldots$ met my needs. } \\
\hline $11 \%$ & $15 \%$ & $6 \%$ & $6 \%$ & $62 \%$ \\
\hline \multicolumn{5}{|c|}{ Statement 22 . By the end of the TEFL/TESOL/ELT program, I'll be ready to teach English. } \\
\hline $2 \%$ & $5 \%$ & $4 \%$ & $1 \%$ & $88 \%$ \\
\hline
\end{tabular}




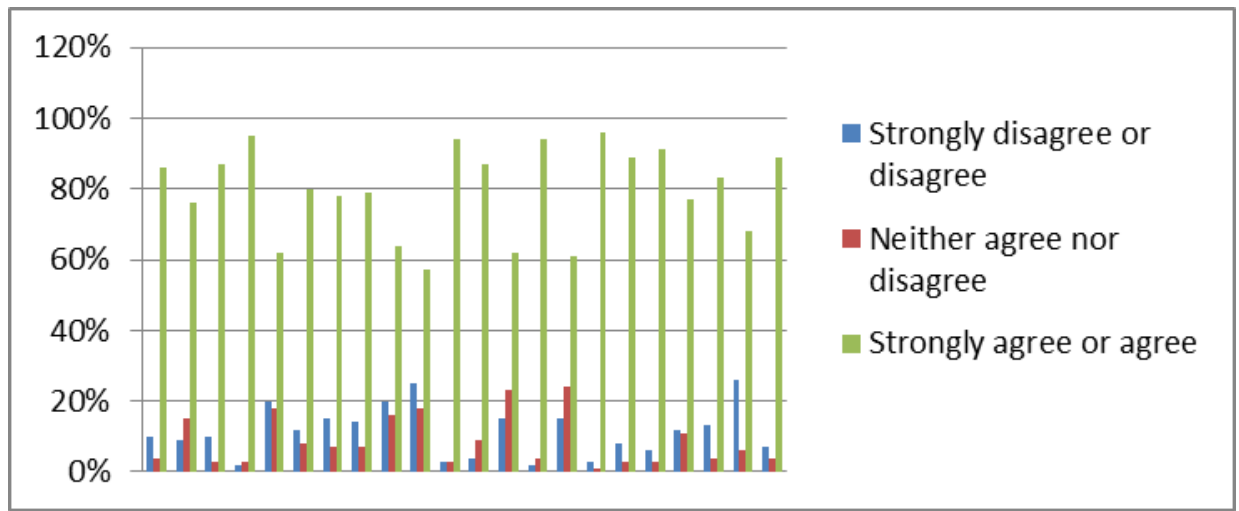

Diagram 3

Student teachers' response about the TEFL program

The information in diagram 3 is precised concerning space issue, and consequently, the statements with above 50\% agreement are emphasized here. Yet the study included Table 1 to indicate the responses in relation to individual scale. Concerning the first research question, the data in the diagram illustrates that on an average, $80 \%$ of the participants affirm regarding the integration of pedagogic competence coupled with English proficiency and management skills in the teacher education program. Such findings reflect no correspondence to those uncovered by Coskun \& Daloglu's (2010) study, in which the pedagogic side of the teacher education program is identified weak. In addition, the current findings also differ from those of Peacock's (2009) study which reports more emphasis on teaching skills then English proficiency and management skills. As such findings of the current study are distinct from those elicited by Agudo's (2017) study, which is commensurate with the results of Peacock's(2009) one.

As shown in Diagram 3, more than $90 \%$ of the respondents endorse that the current TEFL or TESOL or ELT the current program in Bangladesh provide them with adequate training skills with particular concern to how to teach English. In conjunction with these, as the illustration suggests, the same percentage of participants agree that the programs enable them to use foreign language teaching materials. However, the programs do not address the components necessitated to equip them with the ability to adapt foreign language teaching materials, as per the response of the majority $(60 \%)$ of the participants. Yet most of them report that the programs are instrumental to empower them for self evaluation. In addition, more than $90 \%$ of the participants elicit that the programs are relevant to their needs. In contrast, subject to adequate training in teaching skills and how to teach English, Agudo's (2017) study reveals the satisfaction level of $60 \%$ and $53 \%$ of the participants respectively.

Peacock's (2009) study demonstrates that less than half $(48 \%)$ of the participants express satisfaction regarding the program is up-to-date. Surprisingly, Agudo's (2017) study reveals such satisfaction expressed by only $13 \%$ of the participants. Focusing on 
the present study, with regard to the programs linkage between different courses, adequacy in terms of training in English, concern to participants self evaluation as teachers and inclusion of foreign language testing and evaluation skills, more than $80 \%$ of the participants have been identified affirmative. Furthermore, they report that the program is up-to-date, and thereby, substantially prepare them to teach English in the classroom. Such findings become more alive when participants' response concerning their readiness for teaching by the end of the program sheds light on them with $89 \%$ agreement. In contrast, Agudo's (2017) findings suggest that more than half $(58 \%$ and $57 \%$ ) of the respondents perceive a good linkage between different courses in the teacher education program and they found no overlapping information between different courses. His study also suggests that only $26 \%$ of the participants have been seemed affirmative concerning their readiness for teaching at the end of the program, while $35 \%$ of them in Peacock's (2009) investigation have been found possessing such stance. Concerning the preparation for teaching English, $45 \%$ of the participants perceive the effectiveness of the program, while Agudo (2017) founds only $30 \%$ with affirmation. Peacock's study also, in addition, illustrates the satisfaction of less than half of the participants regarding these elements, as demonstrated by $42 \%$ and $35 \%$ agreement respectively. Similarly, Coskun and Daloglu's (2010) study yields 34\% and 24\% satisfaction with regard to the presence of these elements in Turkish context. Yet concerning the avoidance of overlapping information between different courses, encouragement for the student teachers to reflect on their past experiences as a language learner and to be reflective teacher, more than $75 \%$ of the respondents accord their prevalence in the teacher education programs. Additionally, they confirm a good balance between the teaching of: English, teaching skills, and classroom management skills in the programs. Hargreaves and Fullan's (1992) elaboration on teacher development incorporates the idea that focusing on new teaching skills and strategies in teacher education program is inevitable. Anwaruddin (2016) identifies classroom management skill as an essential component of teacher education program. Therefore, two-thirds of respondents' elicitation assures the presence of their balanced entity in the teacher education program, and thereby, notify the effectiveness of the programs. Agudo's (2017) study, on the contrary, delineates that two-thirds of the respondent affirm the endeavor of the program to promote teacher reflection. The response of the students corresponds to that of Chong and Cheah's (2009) study, elaborating the importance of experiential knowledge, provided student teachers need to learn from experience through reflection. According to Wallace (1991), reflection has variety of form. For the first, reflection can take place before the practice. For instance, when reading books or listening to lectures, student teachers can relate the inputs to their professional concerns. And in this phase, it is possible to reflect their past learning experiences. Secondly, it can occur in the shape of recollection. Wallace exemplifies this stating that teachers experience a wide variety of complexities every day. At that time, they can recall the pertinent knowledge and experience to diagnose the problem and solve it. Finally, teachers can reflect what they have learned by participating in the teacher education program on their practice, what calls "reflection-in-action". The final one is particularly important in the sense that this is the stage for examining whether or not the elements learned are practiced by the teachers. Moreover, this stage yields the 
challenges (if any) experienced by the teachers. Such reflection can be a scaffold to investigate teacher education program adopting a systematic approach. According to Tarrau et al. (1999), systematic approach toward the investigation into teacher education program results in new insights preceding revisions, improvements and quality assurance. Therefore, promoting reflective teaching is an indispensable agendum in teacher education programs.

Somewhat $60 \%$ of the respondents have been found to agree that the programs provide them with training for the needs of the Bangladeshi context. They also admit that programs cater flexibility in using different teaching practices in different situations. Coupled with this are certain elements, as the same number of the participants report, entailing classroom management skills and meeting the needs of the student teachers have been found to be present in the programs. However, more than half $(57 \%)$ of the participants perceive that the program balances teacher-centred and student-centred learning on their courses. Addressing the needs of the local context, findings of Peacock's (2009) study, similarly, depict that $52 \%$ of the participants believe that teacher education serves adequate training. Agudo's (2017) investigation uncovers that only $35 \%$ of the respondents admit it. Such result is similar to that divulged by Coskun and Daloglu (2010).

\section{Findings of Qualitative Data}

The study attempted to reveal how the student teachers have found their pre-service education course. The semi-structured interviews were analysed in following themes: clarity of program philosophy; flexibility of the program; focus of the program; capability building for instructional materials; teacher knowledge building.

\section{Clarity of program philosophy}

Concerning the philosophical aspect of the program, student teachers state that the program has clearly stated philosophy. As Teacher Student 1 explains:

I am aware about the philosophy of the program since it is stated clearly in program aim and it is explained in the subject level as well. Collectively, it aims at upgrading the professional skills and classroom practice of the aspiring/practicing teachers of English by using innovation and creativity.

In the interview it was found teachers were very specific about the aim of the program and the philosophy that drives the aim. Some of these teachers could able to explain the aim of the thought subjects.

\section{Flexibility of the program}

Answering whether the programs promote trainee flexibility in using different teaching approaches for different situations, the participant student teachers have been found affirmative.

We mostly are practicing teachers here. We have our job five days in the week. The classes are held in the evening and weekend. Thus, the program promotes flexibility and allows us to attend this. (Teacher Student-5). 
Unlike regular master programs in these universities, these ELT or TESOL or TEFL programs held in the evening, provided that the practitioners will be enrolled in the program promotes the flexibility of the program. However, one of them outlines the infrastructural limitations, which is natural in a context like Bangladesh. He believes the inputs of the program facilitate trainee flexibility to integrate different teaching approaches for different situations, considering the context of Bangladesh.

\section{Focus of the program}

Teacher students were asked about the focus of the program: teacher/student centeredness. Regarding the balance between teacher- and student-centeredness, the focus of the program is to acquaint students a blend of both. Teacher Student 3 explained it elaborately:

In fact in most of the courses that are offered, the initial classes have a bit of teacher-cantered approach in order to acquaint students with fundamentals as they come from diversified backgrounds. But after that, the focus shifts on student activities in the form of class projects, group activities, presentation, panel discussions, question-answer sessions etc. and student-cantered approach takes the lead. Our student teachers thus develop extra shade of confidence to become independent decision-makers as far as TESOL is concerned.

Student Teacher-4 also confirms the presence of teacher- and student-oriented learning in the teacher education program. According to him:

The promotion takes place through the practical teaching classes that our teaching practicum students conduct with young learners. We must demonstrate the balance between teacher- and student-cantered learning to advance our level in the program.

\section{Teacher knowledge building}

Teacher knowledge development is the primary focus of teacher development program. Subjected to the balance of the received versus experiential knowledge, the remark of the student teacher- 8 is as follows:

Our teachers encourage students to drag their real-life experiences and expertise (of those who are already teachers) into the classroom and the class projects make a fine balance between the received and experiential knowledge. Everyone is also required to share their own perceptions and understandings with others.

With similar belief, the other student teacher also affirmed the incorporation of received versus experiential knowledge in the programs.

\section{CONCLUSION}

Given the implication of systematic evaluation of the teacher education programs, as suggested by Tarrau et al. (1999), this study intended to shed light on the components of EFL teacher education programs with a view to identify the areas that demand improvement or the elements that that require revision. Medgyes (1999) expounds that the fundamental concern of English language teacher education program is the language proficiency. The findings yielded from questionnaire conspicuously indicated the 
student teachers' perception. They believed that current TEFL or TESOL or ELT programs substantially equipped them with pedagogic and linguistic competence. The findings suggested that the ongoing TEFL, TESOL and ELT programs yield relatively little emphasis on the context, resulting in student teachers' complexities in the classroom. Teaching concerning classroom management skills is another area to be addressed. The importance of this for teachers is undeniable. Ensuring smooth functioning of classroom lessons and adjusting with the various deviations from students preemptively are the crucial tenets of teaching skills. For elaboration, the current practice in English classroom is mostly student-oriented, requiring teachers' sound command to manage and engage pupils in the classroom activities. Since the focus is on creating a conducive learning atmosphere for students (Eisenman, Edwards \& Cushman, 2015), teachers must have proper and successful access to resources for imparting lessons. According to Moskowitz and Hayman (1976), once teachers lose control of their classrooms, it becomes increasingly more difficult for them to regain that control. As such, the on-going programs should consider this limitation, and with proper initiative, this should be settled. Furthermore, the data suggests that participants lack adaptability with regard to foreign language teaching materials. It is an important expertise to be developed through a teacher education program. Teachers equipped with such expertise are capable enough to fit learning materials convenient for the students. Concerning the encouragement to produce reflective teachers, the student teachers identify the program as relatively less effective. 'Reflection-in-action' is idealized by Wallace (1991), suggesting the impact of the teacher education program on classroom practice. Precisely, these are the aspects to be incorporated in the teacher education program to secure student teachers' maximum attainment. Overall, considering other entities of the teacher education programs in Bangladesh, the satisfaction of the student teacher is documented impressionable.

The strength of our study is the inclusion of wider view in relation to the teacher education programs in an EFL context. The study subsumes the broader vignette of such programs, and investigates the perceptions of the components using multiple lenses. The findings suggest the overall satisfaction concerning the way programs have been designed. Such programs can be initiated in other EFL contexts as well to secure the attainments reported in this study. Moreover, the findings of the current study will also encourage local teachers to enrol in such teacher education programs to be formally equipped with the dexterities required to be an expert language teachers. On top of that, such programs offer a hope of light for English teachers in such context that has long been suffering from inadequate training for English teachers (Karim, Mohamed, Ismail \& Rahman, 2018). Unarguably, teachers' uninspiring teaching strategies and lacklustre classroom management styles are the two prime factors behind the dismal scenario of English classrooms in our secondary level (Shahed, 1998). With little idea regarding the realistic needs of English in their lives, students depend on their teachers to develop their much-needed motivation for learning English. Unfortunately, teachers fail to do so. The impoverishment of our teacher-training programs is evident in such case.

Furthermore, as indicated in the beginning of the article, the pre-service teacher development courses have not been investigated in the context of Bangladesh. This 
would, therefore, contribute to the existing literature in the field by exploring a new EFL context. This study revealed new insights distinctive from other contexts since the contextual impediments that the teachers in Bangladesh's context experience are unique, both in terms of teaching practices and culture. Reporting this will enable practitioners of other contexts to be culturally diverse teachers, which is an attribute to be possessed by $21^{\text {st }}$ century teachers (Kabilan, 2013).

Further research can be carried out in order to examine the impact of such programs. Classroom observation can be incorporated to apprehend teachers' activities and learners' engagement in the classrooms. Our study can be the point of departure for futuristic investigation, given that the results indicate the presence of effective components in the aforementioned programs. However, examining the impact is more pertinent because the ultimate success of the program is determined through observing the practice of the teachers.

\section{REFERENCES}

Akcan, S. (2016). Novice Non-native English Teachers' Reflections on Their Teacher Education Programmes and Their First Years of Teaching. Profile Issues in TeachersProfessional Development, 18(1), 55-70.

Anwaruddin, S. M. (2016). ICT and Language Teacher Development in the Global South: A New Materialist Discourse Analysis. Educational Studies, 52(3), 260-278.

Al-Gaeed, I. H. (1983). An evaluative study of the English as a foreign language teacher preparation programs of Saudi Arabia as preceived by program students and graduate. Unpublished doctoral dissertation, Indiana University, Indiana, USA.

Agudo, J. D. D. M. (2017). What EFL Student Teachers Think about Their Professional Preparation: Evaluation of an English Language Teacher Education Programme in Spain. Australian Journal of Teacher Education (Online), 42(8), 62.

Anderson, L., \&Stillman, J. (2011). Student Teaching for a Specialized View of Professional Practice? Opportunities to Learn in and for Urban, High-needs Schools. Journal of Teacher Education, 62(5), 446-464.

Barkhuizen, G. (1997). Predicted Problems of Elementary School ESL Teachers: Implications for Teacher Education. TESL Reporter, 30(1), 17-26.

Chong, S. and Cheah, H. M. (2009). A Values, Skills and Knowledge Framework for Initial Teacher Preparation Programmes. Australian Journal of Teacher Education, 34(3), 1-16.

Coskun, A., \&Daloglu, A. (2010). Evaluating an English Language Teacher Education Program through Peacock's Model. Australian Journal of Teacher Education, 35(6), 2442.

Creswell, J. W., \& Poth, C. N. (2017). Qualitative inquiry and research design: Choosing among five approaches (4th ed.). Los Angeles, CA: Sage. 
Day, R.R. (1991). Models and the knowledge base of second language teacher education. East Lansing, MI: National center for Research on Teacher learning.

Darling-Hammond, L. (2017). Teacher Education around the World: What Can We Learn from International Practice?. European Journal of Teacher Education, 1-19.

Erozan, F. (2005). Evaluating the language improvement courses in the undergraduate ELT curriculum at Eastern Mediterranean University: A case study. Unpublished doctoral dissertation, Middle East Technical University, Ankara, Turkey.

Flores, M. A. (2005). Teacher's Views on Recent Curriculum Changes: Tensions and Challenges. The Curriculum Journal, 16, 401-413.

Gay, L. R., \& Airasian, P. (2003). Education research: Competencies for analysis and applications. Upper Saddle River, NJ: Pearson.

Hamid, M. O., Sussex, R., \& Khan, A. (2009). Private Tutoring in English for Secondary School Students in Bangladesh. Tesol Quarterly, 43(2), 281-308.

Hargreaves, A., \& Fullan, M. G. (1992). Understanding teacher development. Teachers College Press, 1234 Amsterdam Avenue, New York, NY 10027.

Horowitz, F. D., Darling-Hammond, L., Bransford, J., Comer, J., Rosebrock, K., Austin, K., \& Rust, F. (2005). Educating Teachers for Developmentally Appropriate Practice. Preparing teachers for a changing world: What teachers should learn and be able to do, 88-125.

Kabilan, M. K. (2013). A Phenomenological Study of an International Teaching Practicum: Pre-service Teachers' Experiences of Professional Development. Teaching and Teacher Education, 36, 198-209.

Karakas, A. (2012). Evaluation of the English Language Teacher Education Program in Turkey. ELT Weekly, 4(15), 1-16.

Karim, A., Mohamed, A. R., \& Rahman, M. M. (2017). EIA--A Teacher Education Project in Bangladesh: An Analysis from Diversified Perspectives. International Journal of Instruction, 10(4), 51-66.

Karim, A., Mohamed, A. R., Ismail, S. A. M. M., \& Rahman, M. M. (2018). Organized Hypocrisy in EFL Teacher Training Programs. International Journal of Instruction, 11(2), 437-450.

Medgyes, P. (1999). Language training: A neglected area in teacher education. Nonnative educators in English language teaching, 177-195.

Mehedi, S., Kuddus, M. A., \&Maniruzzaman, M. (2017). The identification ofbankers' perception toward indicators for the adoption of green banking in Bangladeshi scheduled commercial banks. Journal of Internet Banking and Commerce, 22(2).

Musset, P. (2010). Initial Teacher Education and Continuing Training Policies in a Comparative Perspective: Current Practices in OECD Countries and a Literature Review 
on Potential Effects. OECD Education Working Papers, 48. Paris, France: OECD Publishing. https://doi.org/10.1787/5kmbphh7s47h-en

Peacock, M. (2009). The Evaluation of Foreign-language-teacher Education Programmes. Language Teaching Research, 13(3), 259-278.

Rea-Dickens, P. \& Germaine, K. (1993). Evaluation. Hong Kong: Oxford University Press.

Robinson, B. (2004). Evaluation, research and quality. In Teacher education through open and distance learning (pp. 209-227). London, UK: Routledge.

Salli-Copur, D. S. (2008). Teacher Effectiveness in Initial Years of Service: A Case Study on the Graduates of METU Language Education Program. Unpublished doctoral dissertation, Middle East Technical University, Ankara, Turkey.

Shahed, F. H. (1998). English in School Education in Bangladesh: Focus on Urban Schools. (Unpublished M.Phil. dissertation). JNU, New Delhi, India.

Shohel, M M. C., \& Banks, F. (2012). School-based Teachers' Professional Development through Technology-Enhanced Learning in Bangladesh. Teacher Development, 16(1), 25-42.

Seferoglu, G. (2006). Teacher Candidates' Reflections on Some Components of a Preservice English Teacher Education Programme in Turkey. Journal of Education for Teaching, 32, 369- 378.

Tarrou, A. L. H., Opdal, L. R., \&Holmesland, I. S. (1999). Improving Teacher Education through Evaluation: An Analysis of Four Norwegian Case Studies. European journal of Teacher Education, 22(2-3), 135-157.

Wallace, M. J. (1991). Relating theory and practice: The reflective model. Training.

Weir, C. and Roberts, J. (1994). Evaluation in ELT. Oxford: Blackwell.

Zeichner, K. (2010). Rethinking the Connections between Campus Courses and Field Experiences in College-and University-Based Teacher Education. Journal of teacher education, 61(1-2), 89-99.

Zeichner, K., Payne, K. A., \&Brayko, K. (2015). Democratizing Teacher Education. Journal of Teacher Education, 66(2), 122-135. 